\title{
Why individuals fail to collect HIV-test results: an exploratory study at a testing and counseling center in Mexico City
}

\author{
Ester Gutiérrez, ${ }^{1}$ Maria Candela Iglesias, ${ }^{1}$ Francisco Javier Quezada- \\ Juarez, ${ }^{1}$ Evelyn Rodríguez-Estrada, ${ }^{1}$ Gustavo Reyes-Terán, ${ }^{1}$ and \\ Nancy Patricia Caballero-Suárez ${ }^{1}$
}

Suggested citation

Gutiérrez E, Iglesias MC, Quezada-Juarez FJ, Rodríguez-Estrada E, Reyes-Terán G, Caballero-Suárez NP. Why individuals fail to collect HIV-test results: an exploratory study at a testing and counseling center in Mexico City. Rev Panam Salud Publica. 2018;42:e14. https://doi.org/10.26633/RPSP.2018.14

ABSTRACT

Objective. To identify the characteristics of clients at an HIV clinic in Mexico City who fail to collect their HIV test results and to explore the reasons for non-collection.

Methods. This was an exploratory, cross-sectional study that used 2016 program data from the HIV Testing and Counseling Center in Mexico City. Clients with a negative HIV-test result in 2016 were classified as collectors or non-collectors, and their sociodemographic and behavioral characteristics were compared by multivariate logistic regression. A telephone survey was conducted with individuals who failed to return for their results.

Results. In 2016, a total of 729 individuals obtained an HIV negative test result at the Center. Of these, $40 \%(\mathrm{n}=299)$ failed to collect results. In multivariate analysis, having a test requested by a physician, instead of by the individual, was the main variable associated with non-collection. The main reasons reported for not collecting were: unawareness of the collection process $(23.6 \%, \mathrm{n}=21)$, already knowing the result $(22.5 \%, \mathrm{n}=20)$, and scheduling difficulties $(13.5 \%, \mathrm{n}=12)$. In all, $35 \%$ of clients were reached by telephone and $50 \%$ then returned to collect results.

Conclusion. Modifications to the result-delivery system are needed to increase results collection. Improving communication with clients on the collection process and with physicians that request HIV testing could be viable strategies. Alternative ways of delivering results and using rapid HIV are other possible solutions, as long as risk reduction counseling and intervention are still effectively offered.

Keywords HIV; Acquired Immunodeficiency Syndrome; disease prevention; Mexico.

\begin{abstract}
A key challenge to stopping the human immunodeficiency virus (HIV) epidemic is the high number of people living with HIV who are not aware of their status. It is estimated that $49 \%$ of new

\footnotetext{
Departamento de Investigación en Enfermedades Infecciosas of Instituto Nacional de Enfermedades Respiratorias, Mexico City, Mexico. Send correspondence to Ester Gutiérrez, estergutierrezve-
} lilla@hotmail.com
\end{abstract}

HIV transmissions originate from these individuals (1). Worldwide, $40 \%$ of HIV positive people are unaware of their serological status (2); in Mexico, national data puts this number at 37\% (3). To address this problem, it is necessary to encourage HIV testing and ensure that the results are received and understood.

Timely delivery of a positive HIV result is key for early enrollment in antiretroviral therapy and health services, and their associated individual and public health benefits. Likewise, delivering a negative HIV result has important individual and societal benefits: it is an opportunity for discussing risk-reduction strategies with the client $(4-14)$; increases the probability of periodic testing; and facilitates closure of the window periodthe time during which HIV antibodies 
may not be detectable/lead to a false negative result (2) - thus reducing future transmissions (10).

Despite these benefits, $6.5 \%-54.0 \%$ of individuals who undergo an HIV diagnostic test will not collect their results $(7,8,11-13,15$ - 18). Several sociodemographic, behavioral, and structural factors affect result collection $(7,15-17$, 19). Women are significantly more likely to return for results than men $(17,19)$. Sexual orientation (19), age, employment, reason for testing, and the level of perceived risk (7) have also been associated with returning to collect results or not.

The Departamento de Investigación en Enfermedades Infecciosas (Infectious Diseases Research Center; CIENI) of the Instituto Nacional de Enfermedades Respiratorias (National Institute on Respiratory Diseases) has been providing HIV testing and counseling (HTC) services since 2012. Diagnoses are made using the ELISA VIDAS ${ }^{\circledR}$ HIV Panel (bioMérieux, Marcy-l'Étoile, Lyon, France) and Genscreen $^{\mathrm{TM}}$ Ultra HIV (Bio-Rad, Hercules, California, United States) $4^{\text {th }}$ generation non-rapid test. Clients are asked to return to collect results after $3-5$ business days. Individuals with positive HIV results are systematically contacted; however, no such active-contacting procedures are in place for those with negative results, despite the high percentage of negative clients who do not return.

This study aims to analyze the sociodemographic and behavioral characteristics associated with non-collection in individuals with negative results, identify the reasons why these clients do not return for their results, and determine the impact and feasibility of a telephonecontacting strategy.

\section{MATERIALS AND METHODS}

HIV diagnostic tests are offered free of charge through HTC services at CIENI. The HIV informed consent form stipulates that individuals may be contacted for follow up, if necessary.

\section{Design}

An exploratory, cross-sectional study was performed using HTC services data from 2016. Sociodemographic and behavioral data of all clients with negative results were collected retrospectively and compared between "collectors" of the test results and "non-collectors." Clients who met the inclusion criteria were surveyed with a telephone questionnaire that ascertained reasons for noncollection, and were also invited to return to collect results.

\section{Participants}

The first part of the study included clients who had undergone an HIV test on 1 January - 31 December 2016 and had an HIV negative result. The second part of the study-the telephone surveyincluded clients who were $\geq 18$ years of age, had personally given informed consent for the HIV test, had a negative HIV result, and had failed to collect the test result within 30 days.

\section{Measurements}

Sociodemographic characteristics, such as sex, age, marital status, educational level, employment, and sexual orientation; and behavioral data, such as previous HIV tests, reason for testing, and number of sexual partners, were obtained from the routine HTC data collection form. Unit of analysis was the individual and not the test, in order to avoid biases due to clients who had undergone more than one test during the study period. For these multi-testers, data from the most recent test was used for analysis. The outcome variable, i.e., collecting or not collecting the test result was obtained from HTC follow-up data. Non-collection was defined as failing to return for the HIV test results within 30 days after the test.

For the telephone survey, a semistructured questionnaire was used. It included date and time of call, data on the client's identity (name, surname, and phone number), result of the call, and an open-ended question to explore the client's reasons for not returning for the HIV result. In the final part of the interview, the client was offered an appointment for collecting the test result. The first version of the questionnaire was piloted on 20 calls, and adjustments were made accordingly.

\section{Procedures}

Data from the HTC form was collected and anonymized for the analysis. For the telephone survey, data for clients who met the inclusion criteria was copied to a separate list. The list included contact information that a trained health care worker used to try to contact the client at four time-points (May, July, December 2016 and January 2017). At each timepoint, a maximum of two attempts were made per client at two different times during the day. If the individual was located and accepted the interview, the semi-structured questionnaire was applied. Two specialized health researchers categorized the answers to the openended question regarding failure to collect results.

\section{Statistical analysis}

Behavioral data, sociodemographic characteristics, and survey data were analyzed with IBM SPSS Statistics software, version 23 (SPSS Inc., an IBM company, Chicago, Illinois, United States) using frequencies and percentages for descriptive analysis and chi-squared tests to analyze univariate associations between sociodemographic variables and collection of results. Using Stata ${ }^{\circledR} /$ MP14 (StataCorp LP, College Station, Texas, United States), crude odds ratios (OR) were obtained by logistic regression. A multivariate analysis using logistic regression was performed by including sex, age, and variables found to be associated with non-collection in the univariate analysis (educational level and origin of the request) to obtain adjusted ORs, confidence intervals, and $P$ values. The significance level was set at 0.05 .

\section{Ethics}

As mentioned, the HIV informedconsent form stipulates that individuals may be contacted for follow up, if necessary. The Ethics Board of the INER approved the HTC services protocol and associated data collection. All telephone contact was made in accordance with the confidentiality guidelines stipulated in the Official Mexican Norm for Prevention and Control of HIV Infection (20).

\section{RESULTS}

During 2016, the center conducted a total of 877 HIV diagnostic tests for 854 individual clients ( 23 were tested more than once). For multi-testers, data from the most recent test was used for the analysis. Of the 854 clients, $86 \%(n=729)$ tested 
negative. In the majority of cases $(54.9 \%$, $n=468$ ), the request for an HIV test came directly from the individual, while for $385(45.1 \%)$, it came from a physician on behalf of a hospitalized patient.

\section{Characteristics of individuals with HIV negative test results}

Sociodemographics. Of the 729 negative HIV results, $56 \%(n=410)$ were among men. The median age was 38 years (interquartile range $[\mathrm{IQR}]=$
$27-51) ; 42 \%$ reported being single $(n=$ 307); and most were, heterosexual ( $n=$ $493 ; 67.6 \%)$. The majority $(n=623,85.5 \%)$ reported being able to read and write, with $32 \%(n=233)$ having only a primary educational level. Half of the clients $(50.8 \%, n=370)$ reported being employed at the time of testing. Table 1 shows the sociodemographic characteristics for individuals with negative HIV test results.

Behavioral. The median number of lifetime sexual partners reported was four (IQR $=2-10)$. For $48 \%$ this was not the first HIV test they had undergone $(n=350)$. The main reason for soliciting the test was a doctor's request $(69.1 \%, n=$ 504). Other reasons are shown in Table 1.

\section{Associations with non-collection of test results}

Of the individuals with an HIV negative test, $60 \%(n=430)$ collected the result without prompting from HTC services, i.e., before the specified period (30 days).

TABLE 1. Sociodemographic data of HIV negative clients at an HIV testing and counseling center, in Mexico City, Mexico, 2016

\begin{tabular}{|c|c|c|c|c|c|}
\hline \multirow{2}{*}{ Client demographics } & & \multicolumn{2}{|c|}{ Clients with an HIV negative test result } & \multicolumn{2}{|c|}{ Fulfills inclusion criteria for telephone survey } \\
\hline & & $n$ & $\%$ & $\mathrm{n}$ & $\%$ \\
\hline \multirow{2}{*}{ Sex } & Men & 410 & 56.2 & 124 & 57.7 \\
\hline & Women & 319 & 43.8 & 91 & 42.3 \\
\hline \multirow[t]{2}{*}{ Age } & $\geq 18$ years & 670 & 91.9 & 215 & 100.0 \\
\hline & $<18$ years & 59 & 8.1 & & \\
\hline \multirow[t]{6}{*}{ Marital status } & Single & 307 & 42.1 & 81 & 37.7 \\
\hline & Married & 231 & 31.7 & 76 & 35.3 \\
\hline & Lives with partner & 120 & 16.5 & 41 & 19.1 \\
\hline & Separated/Divorced & 39 & 5.3 & 14 & 6.5 \\
\hline & Widower & 20 & 2.7 & 3 & 1.4 \\
\hline & Missing data & 12 & 1.6 & & \\
\hline \multirow[t]{4}{*}{ Sexual orientation } & Heterosexual & 493 & 67.6 & 179 & 83.3 \\
\hline & Homosexual & 70 & 9.6 & 21 & 9.8 \\
\hline & Bisexual & 20 & 2.7 & 3 & 1.4 \\
\hline & Missing data & 146 & 20.0 & 12 & 5.6 \\
\hline \multirow[t]{3}{*}{ Literacy (reads and writes) } & Yes & 623 & 85.5 & 189 & 87.9 \\
\hline & No & 67 & 9.2 & 14 & 6.5 \\
\hline & Missing data & 39 & 5.3 & 12 & 5.6 \\
\hline \multirow[t]{5}{*}{ Educational level $^{\mathrm{b}}$} & No formal education & 105 & 14.4 & 24 & 11.2 \\
\hline & Basic & 233 & 32.0 & 77 & 35.8 \\
\hline & Secondary & 178 & 24.4 & 65 & 30.2 \\
\hline & Higher & 190 & 26.1 & 47 & 21.9 \\
\hline & Missing data & 23 & 3.2 & 2 & 0.9 \\
\hline \multirow[t]{3}{*}{ Employment } & Unemployed & 316 & 43.3 & 94 & 43.7 \\
\hline & Employed & 370 & 50.8 & 110 & 51.2 \\
\hline & Missing data & 43 & 5.9 & 11 & 5.1 \\
\hline \multirow[t]{3}{*}{ Previous HIV tests } & No & 344 & 47.2 & 89 & 41.4 \\
\hline & Yes & 350 & 48.0 & 124 & 57.7 \\
\hline & Missing data & 35 & 4.8 & 2 & 0.9 \\
\hline \multirow[t]{4}{*}{ Reason for the test ${ }^{c}$} & Risk situation & 46 & 6.3 & 6 & 2.8 \\
\hline & Medical reference & 504 & 69.1 & 165 & 76.7 \\
\hline & Routine & 99 & 13.6 & 30 & 14.0 \\
\hline & Relation with HIV+ person & 80 & 11.0 & 14 & 6.5 \\
\hline \multirow[t]{5}{*}{ Number of sexual partners } & $0-2$ & 199 & 27.3 & 73 & 34.0 \\
\hline & $3-5$ & 149 & 20.4 & 55 & 25.6 \\
\hline & $6-9$ & 117 & 16.0 & 37 & 17.2 \\
\hline & $>10$ & 127 & 17.4 & 42 & 19.5 \\
\hline & Missing data & 137 & 18.8 & 8 & 3.7 \\
\hline
\end{tabular}

${ }^{a} \geq 18$ years old, have personally authorized the test, have a negative HIV result, and have not come to collect their result

${ }^{\mathrm{b}}$ Basic is years $4-15$ of schooling; secondary is high school (years 16-18) and/or technical studies; higher education includes university and postgraduate.

${ }^{c}$ Risk situation includes unprotected sexual intercourse and occupational exposure; relation with an HIV+ person includes mother/father with HIV and partner with HIV.

Source: Prepared by the authors from the study data. 
The median time for collection of results was 8 days (IQR = $7-14$ ). The remaining $40 \%$ were considered non-collectors. When comparing collection versus non -collection of results, no associations were found with sex, sexual orientation, number of sexual partners, or having had a previous HIV test.

The univariate analysis performed found that when an HIV test had been requested by a doctor, the client was 2.9 times more likely to be a non-collector than when they had requested the test themselves ( $\mathrm{OR}=3.9 ; 95 \%$ Confidence Interval [95\%CI]: 2.82 - 5.39). Clients with no formal education were less likely to collect results than their counterparts with a secondary level or higher education (none versus secondary $\mathrm{OR}=0.59$; 95\%CI: $0.36-0.96$; none versus higher $\mathrm{OR}=0.42 ; 95 \% \mathrm{CI}: 0.26-0.69)$. Clients whose reason for testing was a doctor's referral were more likely to be non-collectors than those whose reason was a either a routine test $(\mathrm{OR}=0.58 ; 95 \% \mathrm{CI}$ : $0.36-0.93)$, having had relations with an $\mathrm{HIV}+$ person $(\mathrm{OR}=0.32$; 95\%CI: $0.18-$ $0.59)$, or a risk situation $(\mathrm{OR}=0.29$; $95 \% \mathrm{CI}: 0.13-0.65)$. Younger clients were more likely to be non-collectors than those $45-59$ years of age $(\mathrm{OR}=0.48$; 95\%CI: $0.24-0.95)$.

Table 2 shows that in a multivariate model, after adjusting for sex, age, and educational level, origin of the request remained significantly associated with non-collection of HIV test result (aOR = 4.42; 95\%CI: $3.06-6.38$ ).

\section{Reasons for not collecting test results}

The researchers contacted the 215 clients who met the inclusion criteria for the telephone survey ( $>18$ years of age, having personally consented to the test, having a negative HIV result, and being non-collectors). Their sociodemographic characteristics were similar to those of the whole negative HIV test group (Table 1 ). The first attempt at contact was made at a median of 71 days (IQR $=50-104$ ) after testing. Of these 215 non collectors, $56.7 \%$ had been tested at the request of their doctor while they were hospitalized $(n=122)$, and the rest, on their own initiative $(43.3 \%, n=93)$.

Of these 215 calls made, $34 \%(n=74)$ were answered on the first attempt, 53 by the client, and 21 by a relative or friend. On the second attempt, calls were made to 114 individuals; $30.7 \%$ $(n=35)$ were answered, 23 by client and 12 by a relative or friend. After the second attempt and 329 total calls, 109 calls (33.1\%) had been answered and of the

TABLE 2. Variables associated with non-collection of a negative HIV test result from an HIV counseling and testing center, Mexico, 2016

\begin{tabular}{|c|c|c|c|c|c|c|c|c|}
\hline & & & & Nol & ctors & & Univariate Odds Ratio (OR) & Multivariate $\mathrm{aOR}^{\mathrm{a}}$ \\
\hline Variables & & & & & & $\chi^{2}$ & $(95 \% \mathrm{Cl})$ & $(95 \% \mathrm{Cl})$ \\
\hline & & $n$ & $\%$ & $n$ & $\%$ & & & \\
\hline Sex & Men & 254 & 61.9 & 156 & 38.1 & & 1 & 1 \\
\hline & Women & 214 & 67.1 & 105 & 32.9 & 2.6 & $0.8(0.6-1.1)$ & $0.9(0.7-1.3)$ \\
\hline Age, in years & $<14$ & 32 & 61.5 & 20 & 38.5 & & 1 & 1 \\
\hline & $15-29$ & 119 & 64.7 & 65 & 35.3 & & $0.7(0.3-1.3)$ & $1.1(0.5-2.6)$ \\
\hline & $30-44$ & 138 & 60.0 & 92 & 40.0 & 5.2 & $0.8(0.4-1.6)$ & $1.1(0.5-2.6)$ \\
\hline & $45-59$ & 113 & 71.1 & 46 & 28.9 & & $0.5(0.2-0.9)^{b}$ & $0.5(0.2-1.1)$ \\
\hline & $\geq 60$ & 66 & 63.5 & 38 & 36.5 & & $0.70(0.34-1.43)$ & $0.6(0.2-1.3)$ \\
\hline Sexual orientation ${ }^{c}$ & Heterosexual & 330 & 66.9 & 163 & 33.1 & & 1 & \\
\hline & Homosexual & 51 & 72.9 & 19 & 27.1 & 3.7 & $0.7(0.4-1.3)$ & \\
\hline & Bisexual & 17 & 85.0 & 3 & 15.0 & & $0.4(0.1-1.2)$ & \\
\hline Origin of the request & Client & 318 & 77.6 & 92 & 22.4 & & 1 & 1 \\
\hline & Physician & 150 & 47.0 & 169 & 53.0 & $72.8^{b}$ & $3.9(2.8-5.4)^{b}$ & $4.4(3.1-6.4)^{b}$ \\
\hline Number of sexual partners ${ }^{c}$ & $0-2$ & 128 & 64.3 & 71 & 35.7 & & 1 & \\
\hline & $3-5$ & 108 & 72.5 & 41 & 27.5 & 2.9 & $0.7(0.4-1.1)$ & \\
\hline & $6-9$ & 81 & 69.2 & 36 & 30.8 & & $0.8(0.5-1.3)$ & \\
\hline & $>10$ & 89 & 70.1 & 38 & 29.9 & & $0.8(0.5-1.2)$ & \\
\hline Educational levelc & None & 55 & 52.4 & 50 & 47.6 & & 1 & 1 \\
\hline & Basic & 141 & 60.5 & 92 & 39.5 & $12.8^{b}$ & $0.7(0.4-1.1)$ & $0.7(0.4-1.3)$ \\
\hline & Secondary & 116 & 65.2 & 62 & 34.8 & & $0.6(0.4-1.0)^{b}$ & $0.7(0.4-1.3)$ \\
\hline & Higher & 137 & 72.1 & 53 & 27.9 & & $0.4(0.3-0.7)^{b}$ & $0.6(0.3-1.2)$ \\
\hline Reason for the test & Medical reference & 295 & 58.5 & 209 & 41.5 & & 1 & \\
\hline & Routine & 70 & 70.7 & 29 & 29.3 & & $0.6(0.4-0.9)^{b}$ & \\
\hline & Relation with an HIV+ person & 65 & 81.2 & 15 & 18.8 & $25.8^{b}$ & $0.3(0.2-0.6)^{b}$ & \\
\hline & Risk exposure & 38 & 82.6 & 8 & 17.4 & & $0.3(0.1-0.6)^{b}$ & \\
\hline Previous HIV test ${ }^{c}$ & No & 224 & 65.1 & 120 & 34.9 & & 1 & \\
\hline & Yes & 227 & 64.9 & 123 & 35.1 & 0.1 & $1.0(0.7-1.4)$ & \\
\hline
\end{tabular}

${ }^{a}$ Adjusted for sex, age, origin of the request, and educational level $(n=706)$

${ }^{\mathrm{b}} P<0.05$

${ }^{\mathrm{C}}$ There were missing values for this variable.

Source: Prepared by the authors from the study data. 
215 non-collectors contacted, 76 (35.3\%) clients had been located.

The main reasons for not collecting results, as reported by the client or a relative were: "unaware I had to collect the result" $(n=21)$; "I already know the result" $(n=20)$; and "scheduling difficulties" $(n=12)$. In addition, in five cases, a relative reported the client had died. The remaining reasons cited are shown in Table 3.

The majority $(84.2 \%, n=64)$ of the 76 clients located verbally accepted the invitation to return for the HIV result, and $50 \%(n=38)$ actually did. Thus the 2-call localization attempt resulted in an $18 \%$ $(38 / 215)$ secondary collection rate.

\section{DISCUSSION}

Our study highlighted the high percentage $(40 \%)$ of individuals with a negative HIV test result that did not return to collect their result at our center. After multivariate adjustment, non-collection was associated with the test being requested by a physician rather than directly by the client. The main reasons cited by individuals for not collecting results were: unawareness of the need to collect the result, already knowing the result, and scheduling conflicts.

In centers where individuals request an HIV test on their own initiative, the percentage of individuals not collecting the result is lower than in our study, ranging from $6 \%-27 \%$ in developed countries $(8,14-16)$ to $14 \%-30 \%$ in developing countries $(7,13,17)$. However, in studies conducted in clinical settings, where the test was offered by a clinician,

TABLE 3. Reasons reported by clients of an HIV testing center or their relatives for not collecting HIV test results, Mexico City, Mexico, 2016

\begin{tabular}{lcc}
\hline Reason & $n$ & $\%$ \\
\hline Unaware s/he had to collect the result & 21 & 23.6 \\
Already knows the result & 20 & 22.5 \\
Time-schedule problems & 12 & 13.5 \\
Unable to go to the HTC due to poor & 10 & 11.2 \\
$\quad$ health or limited mobility & & \\
Waiting for consultation at the Center & 6 & 6.7 \\
Deceased & 5 & 5.6 \\
Living in another state/province & 4 & 4.4 \\
Forgetfulness & 4 & 4.5 \\
Loss of personal identification & 3 & 3.4 \\
$\quad$ document & & \\
Distance problems & 3 & 3.4 \\
Economical problems & 1 & 1.1 \\
\hline Source: Prepared by the authors from the study & data
\end{tabular}

Source: Prepared by the authors from the study data. the percentage of people not collecting can reach $50 \%$ or more $(11,12,18)$.

Our HTC services are in a tertiary level hospital and provide HIV testing to hospitalized patients upon the physicians request, and to ambulatory external clients who seek the test on their own. Thus, we were able to study both types of client populations. Our results show that physician-requested HIV tests are strongly associated with non-collection of results. This finding is important when taking into account the recommendation by the Centers for Disease Control and Prevention (Atlanta, Georgia, United States; CDC) that HIV testing be offered to all adults and adolescents in the health care setting (21), rather than waiting for the client to request it. Clinicianrecommended testing may have lower result collection rates.

The main reasons reported by HTC services for their clients' failure to return for results were related to institutional and communication issues. Interestingly, the majority $(85.7 \%)$ of individuals who were unaware of the collection process were hospitalized patients whose attending physician had requested the test. This indicates an area of opportunity to improve health professional-patient communication. Prior to discharging the patient, the importance of and procedure for collecting the result must be made clear, especially in the context of this particular infection, which still carries a high stigma even if the test is negative.

Moreover, in some cases, individuals received their results verbally from their attending physician, but the HTC was not informed. This could be why patients were unaware that it is still necessary to collect results directly from the HTC service. This issue points to areas for improvement in internal communications and record keeping. This gap could be filled by having HTC staff seek out physicians who have ordered HIV testing and their patients in order to explain the next steps to the patient. This could reduce the rate of non-collection by $50 \%$.

Structural barriers and difficulties in accessing health services (schedules, mobility problems, distance, financial constraints, etc.) also played an important role in non-collection of results, as reported by interviewees. Extended hours of operation, forwarding results to a clinic more easily accessed by the client, implementing email or telephone results-delivery, as has been piloted by other clinics $(9,22)$, are strategies that might better address the issue of uncollected results.

Another strategy that may prove effective is switching to rapid HIV tests, where the client receives the result in $20-60$ minutes. Rapid tests have been shown to have higher results collection rates $(18,23)$, and in many cases are cheaper (24). However, they have a number of drawbacks as well: sensitivity is lower than that of laboratory tests in most cases (24) and the window period is longer, as most rapid tests are still 3rd generation ELISAs, as opposed to the 4 th generation tests being used in laboratories (24). In addition, rapid tests eliminate the possibility of conducting post-test counseling, after a time of reflection by the client. This post-counseling is important for HIV-prevention $(4-9,12)$ as it reinforces key concepts and the importance of retesting at the end of a window period or periodically; however, it may demand more effort by the client.

This exploratory study showed that two telephone call attempts successfully located one-third of non-collectors who had a negative HIV test result, one-half of whom returned to collect their result. Considering an average of 3 minutes per call answered and 1 minute per call not answered, a health care worker spent a total of 9.1 hours to ensure 38 of 215 patients returned to collect their result. This brings into question the effectiveness of using telephone attempts as a routine procedure; however, this study was not designed to evaluate effectiveness or cost-effectiveness. An important factor that could influence the low number of clients reached could be the fact that call attempts were only done during business hours. Afternoon/evening calls may result in better localization rates. Also, 86 of the 206 calls not answered went to voice mail, suggesting the possibility that a third attempt might reach the individual. Nevertheless, unless there is more sustainable evidence for the use of this strategy, the use of rapid-tests or the delivery of results by telephone with counseling might prove more effective. Any strategy chosen must be put into practice together with strategies for better internal communication between the HTC service and the hospital physicians.

Limitations. In the descriptive part of the study, some important variables, such as perceived risk, perceived stigmatization, and knowledge of HIV or 
socioeconomic level, were not collected and these may be important considerations. Findings on reasons for noncollection may be biased, as only one-third of clients were located. Nevertheless, the characteristics of those located were very similar to those of the 215 individuals called, except for their reason for requesting the test.

\section{Conclusions}

The percentage of people who take an HIV test and do not return for their result is high and is associated with physician-ordered testing. Lack of knowledge on the importance of and process for collecting results, potentially due to inadequate provider-client communication as well as to structural barriers, were important elements contributing to non-collection. Due transmission rates from persons living with HIV who are aware and unaware of their infection. AIDS. 2012;26(7):893-6.

2. World Health Organization. HIV/AIDS 2016. Available from: http://www.who. int/mediacentre/factsheets / fs360/en/ Accessed 14 December 2017.

3. Centro Nacional para la Prevención y el Control del VIH y el SIDA. Informe nacional de avances en la respuesta al VIH y el SIDA. Mexico City: Ministry of Health;2015.

4. Ng'ang'a A, Waruiru W, Ngare C, Ssempijja V, Gachuki T, Njoroge I, et al. The status of HIV testing and counseling in Kenya: results from a nationally representative population-based survey. J Acquir Immune Defic Syndr. 2014;66(Suppl 1):S27-36.

5. Woldeyohannes D, Asmamaw Y, Sisay S, Hailesselassie W, Birmeta K, Tekeste Z. Risky HIV sexual behavior and utilization of voluntary counseling and HIV testing and associated factors among undergraduate students in Addis Ababa, Ethiopia. BMC Public Health. 2017;17:121.

6. Taquette SR, Rodrigues AO, Bortolotti LR. Perception of pre- and post-HIV test counseling among patients diagnosed with aids in adolescence HIV test counseling for adolescents. Cien Saude Colet. 2017; 22(1):23-30.

7. Ngangue P, Bedard E, Ngueta G, Adiogo D, Gagnon M-P. Failure to return for posttest counseling and HIV test results at the prevention and voluntary testing and counseling centers of Douala, Cameroon: an evaluation of a routine five-year program. AIDS Res Ther. 2016;2016:9720148.

8. Laanani M, Dozol A, Meyer L, David S, Camara S, Segouin C, et al. Factors associated with failure to return for HIV test results in a free and anonymous screening centre. Int J STD AIDS. 2015;26(8):549-55. to the important, preventive role of results collection and knowledge of one's HIV status, the process should be adapted to better meet the needs of the client population. Improvements can be made by adequately informing clients on the importance of HIV testing, the process for collecting results, by delivering results more quickly, and by improving accessibility. Timely diagnosis of HIV is a substantial opportunity for improving the health of people living with HIV and reducing the risk of transmission.

Acknowledgements. The authors wish to thank the staff of the Virology Diagnostics Laboratory of CIENI where HIV tests are processed, as well as the administrative and HTC staff of the HIV Testing and Counseling services and the clients who elected to participate.

\section{REFERENCES}

9. Matkovic Puljic V, Kosanovic Licina ML, Kavic M, Nemeth Blazic T. Repeat HIV testing at voluntary testing and counseling centers in Croatia: successful HIV prevention or failure to modify risk behaviors? PloS One. 2014;9(4):e93734

10. Hong NTT, Wolfe MI, Dat TT, McFarland DA, Kamb ML, Thang NT, et al. Utilization of HIV voluntary counseling and testing in Vietnam: an evaluation of 5 years of routine program data for national response. AIDS Educ Prev. 2011;23(Suppl 3): 30-48.

11. Mmbaga EJ, Leyna GH, Mnyika KS, Hussain A, Klepp KI. Prevalence and predictors of failure to return for HIV-1 posttest counseling in the era of antiretroviral therapy in rural Kilimanjaro, Tanzania: challenges and opportunities. AIDS Care. 2009;21(2):160-7.

12. Hightow LB, Miller WC, Leone PA, Wohl D, Smurzynski M, Kaplan AH. Failure to return for HIV posttest counseling in an STD clinic population. AIDS Educ Prev. 2003;15(3):282-90.

13. Downing RG, Otten RA, Marum E, Biryahwaho B, Alwano-Edyegu MG, Sempala SD, et al. Optimizing the delivery of HIV counseling and testing services: the Uganda experience using rapid HIV antibody test algorithms. J Acquir Immune Defic Syndr Hum Retrovirol. 1998;18(4):384-8.

14. Slutsker L, Klockner R, Fleming D. Factors associated with failure to return for HIV post-test counseling. AIDS (London). 1992;6(10):1226-7.

15. Sullivan PS, Lansky A, Drake A. Failure to return for HIV test results among persons at high risk for HIV infection. J Acquir Immune Defic Syndr. 2004;35:7.

16. Chan E, Mcnulty A, Tribe K. Who returns for HIV screening test results? Int J STD AIDS. 2007;18(3):171-4.
Funding. This study was supported by a scholarship from the Consejo Nacional de Ciencia y Tecnología (Mexico City, Mexico; No. 583962). The study was a requirement toward the first author's master's degree under the advisorship of the last. The work of the HTC service is supported by the Comision de Equidad y Género de las legislaturas LX-LXI, and the Comisión de Igualdad de Género de la Legislatura LXII de la $H$. Cámara de Diputados de la República Mexicana.

Conflict of interests. None declared.

Disclaimer. Authors hold sole responsibility for the views expressed in the manuscript, which may not necessarily reflect the opinion or policy of the RPSP/ PAJPH and/or PAHO.
17. Sesay C, Chien LY. Analysis of factors associated with failure to return for an HIVtest result in The Gambia. Afr J AIDS Res. 2012;11(2):83-9.

18. Keenan PA, Keenan JM. Rapid hiv testing in urban outreach: a strategy for improving posttest counseling rates. AIDS Educ Prev. 2001;13(6):541-50.

19. Pahlavan G, Burdet C, Laouénan C, Guiroy F, Bouscarat F, Tosini W, et al. Predictors of return rate for an HIVpositive result in a French Voluntary Counseling and Testing centre. Int J STD AIDS. 2014;26(1):33-6.

20. Secretaria de Salud GF. NORMA Oficial Mexicana NOM-010-SSA2-2010 para la prevención y el control de la infección por Virus de la Inmunodeficiencia Humana. Mexico City: Ministry of Health; 2010.

21. Jover-Diaz F, Cuadrado JM, Matarranz M, Calabuig E. Greater acceptance of routine HIV testing (opt-out) by patients attending an infectious disease unit in Spain. J Int Assoc Provid AIDS Care. 2012;11(6):341-4.

22. Snyder H, Yeldandi VV, Kumar GP, Liao C, Lakshmi V, Gandham SR, et al. Fieldbased video pre-test counseling, oral testing and telephonic post-test counseling: Implementation of an HIV field testing package among high-risk Indian men. AIDS Educ Prev. 2012;24(4):309-26.

23. Grusky O, Roberts KJ, Swanson AN. Failure to return for HIV test results: a pilot study of three community testing sites. J Int Assoc Provid AIDS Care. 2007;6(1):47-55.

24. Brauer M, De Villiers JC, Mayaphi SH. Evaluation of the Determine ${ }^{\mathrm{TM}}$ fourth generation HIV rapid assay. J Virol Methods. 2013;189(1):180-3.

Manuscript received on 12 April 2017. Accepted for publication on 3 August 2017. 
RESUMEN

\section{Por qué las personas no retiran los resultados de las pruebas del VIH: estudio exploratorio en un centro de pruebas y asesoramiento en Ciudad de México}

Palabras clave VIH; síndrome de inmunodeficiencia adquirida; prevención de enfermedades; México.

Objetivo. Determinar las características de las personan que acuden a un consultorio de atención de la infección por el VIH en Ciudad de México y no regresan a retirar los resultados de las pruebas de detección del VIH, y explorar las razones de este comportamiento.

Métodos. Este fue un estudio exploratorio y transversal que usó datos del programa correspondientes al 2016 de un centro de pruebas de detección del VIH y asesoramiento conexo en Ciudad de México. Se clasificó a las personas con resultado negativo en la prueba de detección del VIH en dos grupos, las que "retiraron los resultados" y las que "no retiraron los resultados"; sus características sociodemográficas y conductuales fueron comparadas mediante regresión logística multifactorial. Se realizó una encuesta telefónica a las personas que no regresaron a buscar sus resultados.

Resultados. En el 2016, 729 personas tuvieron un resultado negativo en la prueba de detección del VIH en el centro. De ellas, 40\% $(n=299)$ no acudieron a retirar los resultados. En el análisis multifactorial, la variable principal asociada con el hecho de no acudir a buscar los resultados fue que la prueba hubiera sido solicitada por un médico, en vez de que la persona hubiera acudido por sí misma a realizársela. Las principales razones informadas para no presentarse a buscar los resultados fueron: desconocimiento de que debían ir a buscarlos $(23,6 \%, n=21)$, conocimiento previo del resultado $(22,5 \%, n=20)$ y problemas de horarios $(13,5 \%, n=12)$. En total, se logró contactar por teléfono a $35 \%$ de las personas y $50 \%$ luego acudieron a retirar los resultados.

Conclusiones. Es necesario modificar el sistema de entrega de resultados para aumentar el número de personas que acuden a retirarlos. Algunas estrategias viables podrían ser mejorar la comunicación sobre el mecanismo de entrega de resultados con los pacientes y los médicos que solicitan las pruebas de detección del VIH. Otras soluciones posibles podrían ser mecanismos alternativos para informar los resultados o realización de pruebas rápidas de detección del VIH, siempre que se siga ofreciendo asesoramiento sobre la reducción de riesgos e intervenciones eficaces.
RESUMO

\section{Por que os pacientes não voltam para buscar os resultados do teste do HIV: estudo exploratório em um centro de testagem e aconselhamento na cidade do México}

Palavras-chave
Objetivo. Identificar as características dos pacientes de um serviço ambulatorial especializado em HIV na cidade do México que não voltam para buscar os resultados do teste do HIV e examinar os motivos para não voltarem para buscar os resultados. Métodos. Estudo exploratório transversal realizado com dados de 2016 obtidos em um centro de testagem e aconselhamento de HIV na cidade do México. Os pacientes com resultados negativos no teste de HIV em 2016 foram divididos entre dois grupos: os que voltaram para buscar os resultados e os que não voltaram para buscar os resultados. As características sociodemográficas e de comportamento destes pacientes foram comparadas em um modelo de regressão logística multivariada. Uma pesquisa por telefone foi realizada com os que não voltaram para buscar os resultados do teste. Resultados. Ao todo, em 2016, 729 pacientes tiveram resultados negativos no teste de HIV no serviço ambulatorial. Destes, 40\% $(n=299)$ não voltaram para buscar os resultados. $\mathrm{Na}$ análise multivariada, ter o teste solicitado por um médico, em vez de pelo próprio indivíduo, foi a principal variável associada a não voltar para buscar os resultados. Os principais motivos informados para não voltar para buscar os resultados foram: desconhecimento do procedimento para buscar os resultados $(23,6 \%, n=$ $21)$, saber previamente o resultado $(22,5 \%, n=20)$ e dificuldade para marcar um horário $(13,5 \%, n=12)$. Ao todo, $35 \%$ dos pacientes foram localizados por telefone e $50 \%$ voltaram para buscar os resultados.

Conclusões. É preciso modificar o sistema de informe dos resultados para aumentar o número de pacientes que voltam para buscá-los. Melhorar a comunicação com os pacientes sobre o processo de informe dos resultados e com os médicos que solicitam o teste de HIV poderia ser uma estratégia viável. Maneiras alternativas de informar os resultados e o uso do teste rápido de HIV são outras soluções possíveis, contanto que se continue a oferecer aconselhamento para redução dos riscos e intervenção.

HIV; Síndrome de Imunodeficiência Adquirida; prevenção de doenças; Mexico. 